\title{
E conhecereis o Liberalismo e ele vos libertará: A Deificação do Mercado no pensamento de Mises
}

\author{
Lucio Alves de Barros* \\ Caio César Sousa Marçal**
}

\section{Resumo}

A Religião tem atributos próprios de sua constituição como a noção de sacralidade e da transcendência. Porém, o que dizer quando o secular incorpora próprios elementos da Religião? Nos últimos anos é crescente o interesse sobre a chamada Escola Austríaca de Economia, especialmente por parte de grupos conservadores na obra de Ludwig Heinrich Edler von Mises. O escopo deste trabalho é o de apresentar os principais pontos do referido autor, compreendendo que este faz parte da "escola radical do liberalismo". Nos limites do artigo em apreço, chama-se a atenção para as concepções acerca dos elementos que compõem o liberalismo defendido pelo autor como ele entende a concepção liberal, quais os componentes fundamentais da sociedade, qual o lugar do bem comum e do Estado. O trabalho em questão é de ordem qualitativa e baseado em pesquisa bibliográfica do pensador suíço. Conclui-se que Mises deifica o mercado como um ser que produz uma sociedade superior e harmônica.

Palavras-chave: Mercado. Mises. Religião.

\section{And you will know Liberalism and it will liberate you: The Deification of the Market in the thought of Mises}

\begin{abstract}
Religion has its own attributes of its constitution as the notion of sacredness and transcendence. But what about when the secular incorporates its own elements of
\end{abstract}

* Doutor em Ciências Humanas: Sociologia e Política (UFMG). Mestre em Sociologia (UFMG). Graduado em Ciências Sociais (UFJF). Professor efetivo da Faculdade de Educação (UEMG). Email: luciobarros460@gmail.com

** Mestrando em Sociologia (UFMG). Especialista em Psicopedagogia e Supervisão Escolar (Universidade Cândido Mendes). Graduado em Pedagogia (UEMG). Email: hendrixcaioabu@gmail.com 
religion? Interest in the so-called Austrian School of Economics has grown in recent years, especially from conservative groups in the work of Ludwig Heinrich Edler von Mises. The scope of this paper is to present the main points of this author, understanding that he is part of the "radical school of liberalism". Within the limits of this article, attention is drawn to the conceptions about the elements that make up the liberalism defended by the author as he understands the liberal conception, which are the fundamental components of society, what is the place of the common good and the state. The work in question is qualitative and based on bibliographical research by the Swiss thinker. In conclusion, Mises deifies the market as a being that produces a superior and harmonious society.

Keywords: Market. Mises. Religion.

\section{Y conoceréis el Liberalismo y él os liberará: La Deificación del Mercado en el pensamiento de Mises}

\section{Resumen}

La religión tiene sus propios atributos de su constitución como la noción de santidad y trascendencia. Pero, ¿qué pasa cuando lo secular incorpora sus propios elementos de religión? El interés en la llamada Escuela de Economía de Austria ha crecido en los últimos años, especialmente de grupos conservadores en el trabajo de Ludwig Heinrich Edler von Mises. El alcance de este artículo es presentar los puntos principales de este autor, entendiendo que él es parte de la "escuela radical del liberalismo". Dentro de los límites de este artículo, se llama la atención sobre las concepciones sobre los elementos que componen el liberalismo defendido por el autor al entender la concepción liberal, que son los componentes fundamentales de la sociedad, cuál es el lugar del bien común y el estado. El trabajo en cuestión es cualitativo y se basa en la investigación bibliográfica realizada por el pensador suizo. En conclusión, Mises deifica al mercado como un ser que produce una sociedad superior y armoniosa.

Palabras clave: Mercado. Mises. Religión.

\section{Introdução}

Desde o seu início, as ciências sociais tiveram na religião um locus provilegiado para a compreensão das sociedades. Dentre os assuntos relacionados, por exemplo, trabalhos sobre a presença da religião no espaço público ou da mercantilização da fé, por exemplo. Contudo, seria possível áreas ou discursos como seculares ou mundanos, como é o caso de certas teorias econômicas, cooptar certas características que seriam próprias da religião?

Com a crise do Estado de bem-estar social (welfare-state) nos países desenvolvidos, aberta no final dos anos 70 e início de 80; com a queda do muro de Berlim em 1989, novamente vêm à tona o debate acerca do liberalismo. Pintado com as mais variadas cores, esta doutrina política vai do céu ao inferno. Dos defensores, se espera com certo vigor e galhardia 
a defesa incondicional da liberdade, da livre concorrência, ausência de privilégios e igualdade diante da lei, responsabilidade individual, o imperativo da propriedade privada e o predomínio do mercado como instância mais importante da vida social.

$\mathrm{Na}$ realidade, isto não tem levado a nada, a não ser o aumento da ignorância e à pobreza do debate acerca do que realmente é o liberalismo e quais os seus principais determinantes. Já de início, é forçoso mencionar que se trata de um erro e, muito grave, nivelar todo pensamento liberal. José Guilherme Merquior $(1987,1991)$ talvez tenha sido o autor mais cuidadoso nesse debate. $\mathrm{O}$ autor chama atenção para a necessidade de utilizar o termo "liberalismo" no plural. Assim, estaríamos lidando com liberalismos, que em conteúdo e forma de apreensão e entendimento do mundo real, são muito diferentes. Ao partir do pressuposto de Merquior (1991) da existência de liberalismos, traçaremos nas linhas a seguir reflexões sobre o pensamento de Ludwig Heinrich Edler von Mises, um intelectual da Escola Austríaca, nascido em Lemberg, no antigo Império Austro-húngaro (hoje Lviv, na Ucrânia), no dia 29 de setembro e falecido em Nova York no dia 10 de outubro de 1973.

Nos últimos tempos, parece que Mises tem ganho uma série de adeptos fervorosos, inclusive de conservadores cristãos. O propósito deste trabalho é tentar delinear os principais pontos de vista deste autor, pensador da "escola radical do liberalismo" no qual o mercado é visto como o lugar natural de existência humana e a propriedade privada do corpo e do capital como requisito básico para viver esta existência. Nossa pretensão é simples e sintética e, de forma alguma, incorpora todo o trabalho do autor. Dentre as obras em estudo destacamos: "Liberalismo", "Mercado", "A mentalidade anticapitalista" e "Uma Crítica ao Intervencionismo", por exemplo. O germe do pensamento liberal de Ludwig von Mises (1881 - 1973), pode ser encontrado nos acontecimentos de 1789 ocorridos na França. O movimento era a Revolução Francesa, que derrubou o Antigo Regime e fundamentou os desejos de uma "nova era". As principais bases filosóficas desta concepção são encontradas nos escritos do utilitarista Tomás Hobbes (1588 - 1679) e em John Locke (1632 - 1704). O primeiro defendia que os homens no estado de natureza eram egoístas: “o homem é o lobo do homem”. Para não se matarem uns aos outros decidiram elaborar um pacto. Através da ação humana foi criado um corpo político artificial, o Estado (Leviatã), o qual tinha por função garantir a liberdade e o bem comum dos homens. Por sua vez, Locke partia da definição de direito natural. O Estado tem por finalidade garantir o direito 
natural de propriedade, incluindo a vida, a liberdade e os bens alcançados pelo trabalho que, segundo ele, era necessário para a conservação dos bens.

Nesse trabalho discute-se a concepção desse ator acerca da ação humana, da liberdade, e da propriedade privada dos recursos de produção. Além disso, analisamos o problema da igualdade de oportunidades, chamando atenção para o lugar do Estado, dos mecanismos de mercado e dos agentes econômicos. Finalmente, descrevemos o lugar do mercado em sua teoria. O mercado aparece como chave de toda engrenagem do pensamento teórico de Mises, levando o autor ao ponto de deificar esta instituição.

\section{A Liberdade em Mises}

Um dos principais imperativos liberais de Mises é a liberdade. Liberdade entendida de forma negativa, caracterizada como ausência de coerção ou constrangimento exercido por terceiros. O homem nasce livre e assim deve continuar. A ninguém é dado o direito de interferir na liberdade do outro para usufruir de um bem ideal ou material.

Somente no contexto de um sistema social é que se pode atribuir um significado à palavra liberdade. No sentido praxeológico, o termo liberdade refere-se à situação na qual um indivíduo tem a possibilidade de escolher os seus fins e os meios a empregar para atingi-los. A liberdade de um homem é rigidamente restringida pelas leis da natureza, bem como pelas leis da praxeologia. Ele não pode pretender atingir fins incompatíveis entre si (Mises, 1987 c, p. 58 e 59$)$.

Nessa linha de argumentação, os seres humanos são livres na medida em que podem escolher os seus próprios objetivos e cursos de ação, em que podem escolher livremente entre alternativas que estão à disposição, em que não são constrangidos a agirem da forma que não escolheriam, ou que não são impedidos de agir de modo que preferiria a vontade de outro (o Estado por exemplo). Estamos nos referindo a uma concepção negativa de liberdade. Tal como destacou Berlin (1981), liberdade entendida como ausência de coerção exercida por outrem ${ }^{1}$. O que não significa dizer que

\footnotetext{
1 BERLIN, Isaiah. Dois conceitos de liberdade. In Quatro ensaios sobre a Liberdade. Brasília: Ed. UNB (Universidade de Brasília), 1981. Para uma análise crítica do conceito de liberdade negativa e liberdade positiva, que vê nesta diferenciação um "falso problema", conferir o artigo de MACCLLUM, G. C.. Negative and Positive Freedom. In MILLER, David (ed.). Liberty. Oxford University Press, Oxford, 1991.
} 
não estamos delimitados por contingências, normas, costumes, conjunturas sociais e condições físicas. De acordo com Mises:

...seria absurdo dizer que o homem não é livre porque não pode, digamos, drogar-se, sem sofrer as inevitáveis consequências consideradas como altamente indesejáveis. Embora isso seja evidente para todas as pessoas de bom senso, esta evidência não é bem percebida em situações análogas sujeitas às leis da praxeologia". Ainda no mesmo terreno, cabe aos seres humanos escolherem entre "o respeito a certas regras que tornam a vida em sociedade possível ou a pobreza e a insegurança, se preferir viver perigosamente, num estado de guerra constante entre indivíduos independentes. Esta é uma lei tão exata na determinação do resultado da ação humana como um todo, quanto o são as leis da física (Mises, 1987c, p. 59).

O liberalismo de Mises é uma doutrina inteiramente voltada para a ação e conduta dos homens no mundo. Tem por objetivo a garantia do progresso e do bem-estar material dos seres humanos e nada diz a respeito de necessidades interiores: aspirações religiosas, metafísicas e espirituais. Não promete felicidade e contentamento, mas aposta na possibilidade da maior satisfação possível dos desejos humanos, suscitados pelas coisas e pelo mundo exterior.

Alicerçado na razão, e tendo a liberdade como valor supremo, Mises acredita que o liberalismo é um sistema que assegura maior produtividade do trabalho humano, sendo interesse de todos viver em cooperação, já que esta aparece como a melhor forma de obter bons resultados através da divisão do trabalho. $\mathrm{O}$ ser humano se distingue dos animais, tal como vimos nas concepções de Adam Smith, devido as práticas de troca e a divisão da capacidade laboral. Ao dividir o trabalho, soube explorar a terra ("tudo que a natureza coloca à nossa disposição, na forma de substâncias e de energia nela encontradas, sob e acima de sua superfície, na água e na atmosfera" (MISES, 1987b, p. 50) e constituir o capital (máquinas, ferramentas, artigos semimanufaturados etc.).

Mises destaca dois sistemas de cooperação alicerçados na divisão do trabalho: aquele que se baseia na propriedade privada dos meios de produção e o que se assenta na propriedade comunal. Comecemos pela crítica a esta última. Para o liberal austríaco nada justifica um sistema que usurpa a liberdade dos indivíduos. Ao furtar a possibilidade do homem em viver sua própria liberdade, estamos cerceando sua capacidade criativa, ação e conduta 
rumo a dias melhores. Estamos retirando sua capacidade de poupar e fazer multiplicar o capital empregado. Para Mises, em tais condições, homens e mulheres estão vivendo para o Estado e sua máquina burocrática recheada de lideranças políticas sedentas de poder. Ao tirar a propriedade privada (incluindo aqui a do próprio corpo) o interventor submete os indivíduos aos tecnocratas. O resultado é drástico, pois o resultado da intervenção nunca é o desejado pela maioria da população, ou mesmo pelo próprio interventor. Intervir no mercado é beneficiar uma parte dos consumidores e, inevitavelmente, produzir consequências desagradáveis para a maioria dos cidadãos. No que concerne ao sistema baseado na propriedade privada dos meios de produção, Mises não se cansa de tecer elogios:

Os liberais mantêm a opinião de que o único sistema de cooperação humana que, de fato, funciona numa sociedade, baseada na divisão do trabalho, é a propriedade privada dos meios de produção. (...) o programa do liberalismo, se pudermos condensá-lo em uma única palavra, se resumiria no termo propriedade, isto é a propriedade privada dos meios de produção (pois, no que se refere às mercadorias prontas para o consumo, a propriedade privada é um fato, e isto não é questionado pelos socialistas e comunistas). Todas as outras exigências do liberalismo resultam deste requisito fundamental (Mises, 1987b, p 21).

É preciso chamar atenção para o fato de que o imperativo da propriedade privada está associado à plena liberdade de entrada no mercado. De acordo com o sistema de informações (preços, lucros etc), os capitalistas, legítimos proprietários de seus bens, vão ao mercado disputar a atenção e o gosto do consumidor. Para Mises, no mercado capitalista sempre veremos triunfar aqueles capazes de produzir algo melhor e mais barato para o público em necessidade. Diferentemente de outros modelos de produção, nas sociedades capitalistas não é o trabalhador o ator mais importante da modernidade. Para Mises, o modelo de produção, alicerçado na propriedade privada dos meios de produção, elegeu como único e mais importante soberano o consumidor.

No mercado de uma sociedade capitalista, o homem comum é o consumidor soberano, aquele que, ao comprar ou ao se abster de comprar, determina em última análise o que deve ser produzido e em que quantidade. As lojas e fábricas que suprem exclusiva ou predominantemente os pedidos dos cidadãos mais abastados em relação a artigos de luxo exercem apenas um 
papel secundário no cenário econômico do mercado. Elas nunca atingem a dimensão da grande empresa. As grandes empresas servem sempre - direta ou indiretamente - às massas (Mises, 1987a, p. 8).

O consumidor, a liberdade de entrada no mercado e a garantia da propriedade privada dos recursos de produção garantem um dos mais interessantes fenômenos do mercado, a competição. Isto não significa, é claro, que não exista competição quando empresas estatais operam no mercado, significa que dificilmente teríamos empresa deste porte (estatais) longe de privilégios e desmandos burocráticos de suas lideranças. Ela persiste e compete dignamente no mercado apenas quando atende os interesses dos consumidores.

A competição para Mises é o caminho e a condição necessária para a harmonia e cooperação social. Diferentemente dos animais, disputamos os escassos bens de subsistência não através de conflitos que podem levar à morte. Fazemos acordos, trocamos o que podemos oferecer por outras coisas que satisfaçam nossas necessidades². É por isso que vivemos em sociedade e não em ilhas, dado que precisamos uns dos outros para sobreviver. A consciência que temos da necessidade do outro colabora para que vivamos em harmonia. Mas isso não significa que não competimos no mercado.

A competição biológica não deve ser confundida com a competição social, isto é, o esforço dos indivíduos para obter uma posição mais favorável no sistema de cooperação social. Como existirão sempre situações às quais os homens atribuem mais valor, as pessoas se esforçarão por alcançá-las e tentarão superar os seus rivais. A competição social, consequentemente, está presente em qualquer forma concebível de organização social (Mises, 1987a, p. 48).

A motivação que os seres humanos carregam no intuito de superar uns aos outros Mises chama de competição cataláctica definida da seguinte maneira:

A competição cataláctica é uma emulação entre pessoas que querem superar uma às outras. Não é uma luta, embora seja comum o emprego, num sentido metafórico, de termos como ataque e defesa, estratégia e tática, extraídos da terminologia da guerra e dos conflitos violentos. Na competição cataláctica, aqueles que perdem não são aniquilados; são deslocados para um lugar mais compatível com as suas realizações do que aquele que pretendiam alcançar (Mises, 2017, p. 582).

Consoante ao autor: "A cooperação social sob o signo da divisão do trabalho elimina tais antagonismos. Substitui a hostilidade pela associação e mutualidade. Os membros da sociedade são solidários numa aventura comum”. (MISES, 1987a, p. 48) 
Mises ainda afirma que podemos observar sociedades sem competição social, tal como as sociedades socialistas e comunistas, cujo chefe atribui direitos e deveres a cada indivíduo. Os indivíduos não têm ambição, somente o Estado e não existe motivação num modelo social como este. Ele não produz ambições, uma vez que os indivíduos são indiferentes quanto à busca de posições na sociedade. Homens e mulheres se "comportar-se-iam como os cavalos reprodutores de um haras, que não procuram colocar-se num ângulo mais favorável quando o proprietário escolhe o garanhão que vai cobrir sua melhor égua. Mas tais pessoas já não seriam agentes humanos" (MISES, 2017, p. 582).

A competição, como fenômeno social, entretanto, invade todas as esferas da vida. No mercado ela é a "menina dos olhos" dos consumidores. Mises afirma que, havendo a liberdade de entrada no mercado e a possibilidade de lucros, é inevitável que os donos dos meios de produção apostarão na maior produtividade e, consequentemente, vão estar motivados em competir no mercado pelo gosto do consumidor. Isto se dá porque, quanto maior a liberdade de entrada no mercado, maior a competição. O resultado é a satisfação do consumidor, pois a competição tende a abaixar os preços e lucros daqueles que estão competindo no mercado. A vitória, obviamente, é daqueles que melhor atenderem o público.

\section{A igualdade de oportunidades}

A todos é garantida a liberdade de entrada, competição no mercado, acesso a bens e direito a ter lucros. Não é certo a garantia de privilégios, fraudes e uso da violência. Daí a importância do Estado para a manutenção da paz e da harmonia social. Estas são as premissas necessárias para a competição cataláctica. Como vimos, Mises observa que esta competição é um dos traços característicos da economia de mercado e que se trata de "um fenômeno social". Nesse contexto acredita que estamos fadados a competir, sob pena de sermos jogados a um lugar menos privilegiado na sociedade, seja qual for a esfera de atuação escolhida por nós.

É forçoso argumentar se é possível garantir oportunidades iguais a todos que pretendem competir. Mises argumenta que não cabe a qualquer instância (principalmente o Estado) garantir tais oportunidades. O ganho ou a perda no mercado é resultado da avaliação consciente do consumidor, o soberano nas economias capitalistas de mercado: 
... atribuir a cada um o seu lugar próprio na sociedade é tarefa dos consumidores que, ao comprar ou abster-se de comprar, estão determinando a posição social de cada indivíduo. A soberania do consumidor não diminui quando são concedidos privilégios a indivíduos na qualidade de produtores" (Mises, 2017, 383).

Para Mises, produtores e consumidores, na verdade podemos ser ambos, garantem a distribuição dos bens disponíveis e o lugar que teremos na sociedade. A entrada no mercado, por exemplo, é garantida para todos. Mas o mesmo não se pode afirmar sobre a continuidade dos mesmos, visto que podem ser destruídos e/ou afastados diante da acirrada competição. E isto não ocorre só no jogo da oferta e da procura de bens materiais. O mesmo Mises defende no campo dos bens ideais. A vitória pertence àqueles que conseguem atender aos interesses imediatos do consumidor.

É comum condenar o fato de a competição cataláctica não oferecer a todos as mesmas oportunidades. O começo é muito mais difícil para um menino pobre do que para o filho de um homem rico. Mas os consumidores não estão interessados em saber se aqueles que os servem começaram suas carreiras em condições de igualdade. Seu único interesse é assegurar a melhor satisfação possível de suas necessidades (Mises, 2017, 385).

Realmente, é sempre possível ouvir pesadas críticas à competição, principalmente devido a inexistência de igualdade das oportunidades. Mises não se importa com os críticos, apenas ressalta que não está em jogo a "posição original” do indivíduo. O fato é que os seres humanos possuem "naturalmente" desigualdades fisiológicas inerentes à sua condição. Os seres humanos nascem diferentes em graus de inteligência, talentos, força de vontade, beleza e destreza física. ${ }^{3}$ Não há dúvida que o corpo, a beleza física da bailarina ou da artista de televisão; a habilidade do jogador de futebol; o talento de um compositor e cantor aumentam significativamente as chances de melhor se posicionar na sociedade. O mesmo podendo-se dizer dos indivíduos oriundos de famílias abastadas e proprietárias.

3 Em Liberalismo, este argumento aparece da seguinte forma: "Nada mais infundada do que a afirmação da suposta igualdade de todos os membros da raça humana. Os homens são totalmente desiguais. Mesmo entre irmãos, há diferenças das mais marcantes, quer nos atributos físicos, quer nos mentais. A natureza nunca se repete em sua criação; não produz nada á dúzias, nem são padronizados os seus produtos. Cada homem que nasce de sua fábrica traz consigo a marca do indivíduo, único e irrepetível”. (Mises, 1987b, p. 30 e 31). 
De acordo com Mises, é impossível e ilusório o fim das desigualdades tanto na natureza como no campo social, político e econômico. $\mathrm{O}$ economista austríaco se distancia, nesse caso, dos liberais do século XVIII que, guiados pelo ideário da lei natural e do Iluminismo, exigiam igualdade de direitos civis a todos os homens e mulheres. Homens e mulheres são iguais. Mas, para Mises, a desigualdade não é apenas inata, ela toma novos contornos quando chega no mercado e se encontra sob o julgo do consumidor. As tentativas de criar uma igualdade de oportunidades através de desvantagens compensatórias (um imposto especial, talvez) sobre os mais afortunados, Mises acha a ideia absurda, dado que nada garante que elas não vão continuar. O consumidor não tem as mesmas preferências, ele não quer saber se o sujeito economicamente mais favorecido recebeu seus bens por hereditariedade ou não, ele quer é satisfazer suas necessidades da maneira que melhor lhe convém:

Como, nesse sentido (o de melhor satisfação de necessidades) o sistema de transmissão hereditária funciona melhor, eles o preferem em vez de outros sistemas menos eficientes. Consideram as coisas do ponto de vista da conveniência e do bem-estar sociais e não do ponto de vista de um alegado, imaginário e irrealizável direito natural de cada indivíduo competir com chances iguais. Para tornar real este direito, seria necessário colocar em desvantagem os que nascem mais bem dotados intelectualmente e com maior força de vontade que a maioria das pessoas. É óbvio que isso seria um absurdo (Mises, 1987b, p. 52, 53).

O mesmo diagnóstico é encontrado em relação às desigualdades econômicas. Duas crianças: uma pobre e outra rica. Para solucionar o problema bastaria dividir a riqueza entre elas? Bastaria por fim ao direito de herança? Caberia ao Estado garantir a igualdade de oportunidades? Para o autor, tais possibilidades chegam a ser cômicas... "porque os de poucas posses superam, em muito o número de ricos, de tal modo que cada indivíduo nada poderia esperar dessa distribuição, a não ser um aumento insignificante de seu padrão de vida” (MISES, 1987b, p. 33).

Para Mises, o objetivo primeiro de toda ação humana é a satisfação de seus interesses, necessidades e confortos. Homens e mulheres são racionais, não agem no intuito de produzir a igualdade de oportunidades. As instituições sociais são criadas à medida que se faz necessário atender os interesses demandados pela motivação humana. Se os seres humanos apostassem 
na distribuição de riqueza e na igualdade de oportunidade, certamente se configuraria uma situação econômica onde a maioria das pessoas estariam em melhor situação. Entretanto, ao mesmo tempo, assistiríamos ao empobrecimento daqueles que abriram mão ou foram obrigados a se desfazer de suas riquezas. Esta realidade seria inconcebível. Para Mises, obrigar os indivíduos a abrirem mão de suas riquezas é atentar contra sua liberdade. Liberdade não apenas política, mas também a de acumulação de capital. Sobre os argumentos contrários ao imperativo da distribuição de riquezas, Mises ainda ressalta a seguinte observação:

Os que defendem a igualdade de distribuição de renda, desconsideram o ponto mais importante, a saber, que o total disponível para a distribuição, o produto anual do trabalho social, não é independente do modo pelo qual é dividido. $\mathrm{O}$ fato de que esse produto alcança seu nível atual não é um fenômeno natural ou tecnológico, independentemente de todas as condições sociais, mas é, em sua totalidade, o resultado de nossas instituições sociais. Simplesmente pelo fato de a desigualdade da riqueza ser possível em nossa ordem social, simplesmente pelo fato de estimular a que todos produzam o máximo que possam, é que a humanidade hoje conta com toda a riqueza anual de que dispõe para consumo (Mises, 1987b, 33).

Acabar com a possibilidade de desigualdade de renda, nesse sentido, é desestimular os seres humanos a uma maior produtividade e criação de dias melhores. Sem esta motivação para o ganho, certamente estaríamos vivendo nas mesmas condições daqueles que habitavam o tempo histórico da Idade Média, afirma Mises (1987c). Não há relevância nas discussões referentes a “posição original” dos indivíduos, tal como quer Rawls (1971). São águas passadas, diria Mises: "a desigualdade de riqueza e de renda é uma característica essencial da economia de mercado" (MISES, 2017, p. 72). Mas todos devem e podem reverter a situação de desfavorecimento econômico vigente na ordem capitalista. Isto não é possível em sociedades comunistas, ditatoriais e socialistas. Nestas não há liberdade. E se alguns conseguem se alçar no poder político ou econômico, é porque lhes foram reservados privilégios.

No sistema de economia de mercado, caberia aos indivíduos trabalhar, poupar, cooperar para o aumento da riqueza individual e, consequentemente, coletiva. O processo é seletivo: os mais aptos no atendimento do consumidor permanecem nas posições privilegiadas. Existe competição, mas também seleção dos melhores: "ninguém pode considerar sua posição como assegurada 
e não existe nenhum direito que garanta uma posição conquistada no passado" (MISES, 2017, p. 199). Nesse caminho, não se deve desagradar ao consumidor, sob pena de sofrer punição. Entretanto, pode-se esperar um mundo em "harmonia", com conforto e cooperação.

O processo de seleção que ocorre no mercado é impulsionado pela combinação de esforços de todos os participantes da economia de mercado. Motivado pelo desejo de diminuir tanto quanto possível o seu próprio desconforto, cada indivíduo procura, por um lado, colocar-se numa posição que lhe permita contribuir ao máximo para que as demais pessoas tenham a maior satisfação possível e, por outro lado, tirar o melhor proveito dos serviços por elas oferecidos. Em outras palavras: tenta vender no mercado mais caro e comprar no mercado mais barato. A resultante desses esforços é não apenas a estrutura de preços, mas também a estrutura social, a atribuição de tarefas específicas aos vários indivíduos (Mises, 2017, p. 199).

Mises afirma que o processo de seleção "não para nunca" e, tal como o processo de competição, invade todas as esferas da vida. O modelo capitalista de mercado é implacável ao punir os que não seguem as regras da competição. Nada está acabado. Tudo se transforma: "a economia de mercado é o produto de um longo processo evolucionário" e não tem fim. O que se sabe é que homens e mulheres continuam a se esforçar no intuito de melhor ajustar suas ações rumo a criação de um mundo melhor. É óbvio que muitos ficam pelo caminho, não acompanham as modificações ou são incapazes de competir no mercado. No meio de produção capitalista, delineado por Mises, a situação dos indivíduos depende dos seus próprios feitos. Aqueles que não aproveitaram as oportunidades são incompetentes. Foram testados pelo mercado e não agradaram, não podem sobreviver em um regime cujo principal objetivo é atender da melhor maneira o consumidor.

O mercado torna as pessoas ricas ou pobres, determina quem dirigirá as grandes usinas e quem limpará o chão, fixa quantas pessoas trabalharão nas minas de cobre e quantas nas orquestras sinfônicas. Nenhuma dessas decisões é definitiva: são revogáveis a qualquer momento. O processo de seleção não para nunca. Vai adiante ajustando o aparato social de produção às mudanças na oferta e na procura. Revê, incessantemente, suas decisões prévias e força todo mundo a se submeter a um reexame de seu caso (Mises, 2017, p. 199).

No "melhor dos mundos possíveis" delineado por Mises, não há lugar para fraudes nem roubos. A harmonia social seria espontânea, haja vista que 
todos, ao terem consciência de suas potencialidades, sabem o quanto devem investir para viver em sociedade. Se não o fazem, é porque não o querem. As oportunidades estão disponíveis no mercado. Nele é permitida a entrada de todos, desde que queiram competir, que queiram seguir as regras do jogo visando o melhor atendimento do público consumidor.

A tão falada dureza do capitalismo consiste no fato de ele tratar cada um de acordo com a contribuição que este oferece ao bem-estar do seu semelhante. A força do princípio a cada um de acordo com seus feitos não dá margem a escusar falhas pessoais. $\mathrm{O}$ indivíduo sabe muito bem que existem pessoas iguais a ele que obtiveram sucesso onde ele falhou. Sabe que muitos daqueles que inveja são pessoas que se fizeram pelo próprio esforço e que partiram do mesmo ponto onde ele começou. E, muito pior, sabe que os outros também sabem disso. Ele vê nos olhos da mulher e dos filhos a reprovação silenciosa: "Por que você não foi mais esperto?" Ele vê como as pessoas admiram quem obteve mais sucesso do que ele e como contemplam com desprezo ou com piedade o seu fracasso (Mises, 1987a, p. 16 e 17).

Quanto à impossibilidade do mercado em contemplar a todos, Mises acredita na possibilidade, cumprindo ao "pretendente a produtor" saber agradar o consumidor com melhores preços, mercadorias e qualidade. Apostar e perder no mercado é sinal de que o indivíduo fracassou, não atendeu de forma conveniente o próximo. Não teve os melhores preços, tampouco soube ouvir as vozes do mercado. É um indivíduo derrotado.

\section{O Estado}

Tal como o liberal a vê a tarefa do Estado consiste, única e exclusivamente, em garantir a proteção da vida, a saúde, a liberdade e a propriedade privada contra ataques violentos. Tudo que vai além disso é mau (Mises, 1987b, p. 53).

Chamamos de Estado o aparelho social de compulsão e coerção, que induz as pessoas a obedecerem às regras de vida em sociedade; chamamos de Lei as regras, segundo as quais o estado age; e de governo, os órgãos encarregados da responsabilidade de administrar o aparelho coercitivo (Mises, 1987b, p. 38).

Como se vê, não cabe ao Estado a interferência nos rumos da economia. $\mathrm{Na}$ sociedade e na política a interferência é limitada, o Estado apenas exerce a função de vigilância. Nada de galgar propriedades coletivas e serviços públicos que atingirão a todos. Deve o Estado garantir saúde, 


\section{Lucio Alves de Barros \\ Caio César Sousa Marçal}

segurança, paz e liberdade. Tudo isso para que os indivíduos possam livremente buscar a satisfação de seus interesses no mercado e diminuindo o desconforto inicial. Obviamente, se faz necessário um sistema de justiça (leis) e um governo capaz de administrá-la. Vimos, em linhas atrás, que o mercado nada mais é do que um fenômeno social resultado da "cooperação" entre os seres humanos. Isto implica em criação de regras: "não posso matar" aqueles que competem comigo. Também “não devo roubar” meus oponentes. A regra está acima dos instintos humanos. É isso também que nos diferencia dos animais.

No entanto, nada justifica o Estado invadir a liberdade dos indivíduos. A liberdade é um contrato entre iguais, conforme Mises. É o meio mais propício de que os seres humanos encontraram para a convivência social alicerçada no intercâmbio espontâneo de mercadorias. Homens e mulheres, há muito já descobriram a necessidade de uma organização social estruturada em normas e regras institucionalizadas por acordos legítimos entre os cidadãos com intuito de manutenção da paz e da justiça. Portanto, na concepção de Mises, o liberalismo pressupõe a existência de um Estado organizado, que tenha o monopólio legítimo do uso da violência e da coerção. Em suas palavras:

O liberal compreende perfeitamente que, sem o recurso da coerção, a existência da sociedade correria perigo e que, por trás das regras de conduta, cuja observância é necessária para assegurar a cooperação humana pacífica, deve pairar a ameaça da força, se todo o edifício da sociedade não deve ficar à mercê de qualquer de seus membros. Alguém tem de estar em condições de exigir da pessoa que não respeita a vida, a saúde, a liberdade pessoal ou a propriedade privada de outros, que obedeça à regras da vida em sociedade. É esta a função que a doutrina liberal atribui ao Estado: a proteção á propriedade, a liberdade e a paz (Mises, 1987, p. 39).

O Estado seria para Mises um “mal necessário”. O sonho de um liberal é viver em uma sociedade onde ele não exista. De todo modo, tem a consciência de que se trata de uma utopia difícil de ser alcançada. De acordo com Mises, é este pensamento que diferencia o liberal de um anarquista, o liberal tem consciência que terá que viver e morrer em uma sociedade administrada por forças estatais. O máximo que ele pode fazer é limitar ao máximo sua ação. As regras, nesse caso, são importantes e devem ser utilizadas apenas para garantir o cumprimento dos contratos. É preciso chamar atenção para os limites impostos à ação estatal. Eles dizem respeito basicamente aos direitos individuais que o homens e mulheres já possuem, e 
que de forma alguma devem ser-lhes tirados: o direito à vida, à propriedade privada, à liberdade, à saúde e a paz. Para um liberal,

É evidentemente, um equívoco considerar que o homem tem direito a ter aquilo que não tem. Assim, o direito à casa própria, ao emprego e a tudo o mais que quisermos listar como direito representa apenas o desejo de possuir algo e o expediente de pretender obtê-lo tomando de alguém (Mises, 1987b, p. 39).

Ao Estado é delegado a tarefa de administrar o aparato estatal da força. Cabe ao Estado punir o cidadão que não resiste aos acordos firmados consensualmente. Aos governantes se espera lisura e competência nas regulamentações. Proteger a vida, a liberdade e a propriedade, é garantir um ambiente institucional e o respeito às regras capazes de fazerem florescer os talentos e a criatividade dos pactuantes do acordo. Em poucas palavras: "é garantir a ordem e a justiça".

O governo é constituído de umas poucas pessoas (os governantes são sempre uma minoria entre àqueles a quem governam, tanto quanto o são os fabricantes de sapatos, em relação aos consumidores de seus produtos) e depende do consentimento dos governados, isto é, da aceitação da administração em exercício. Os governados podem considerá-lo um mal menor, ou um mal inevitável, embora possam ser de opinião de que uma mudança da situação reinante não teria propósito algum. Mas uma vez que a maioria dos governados se convence de que é necessária e possível a mudança da forma de governo e a substituição do velho regime e dos seus governantes, os dias deste estão contados. A maioria terá poder de levar a efeito seus propósitos pela força, mesmo contra a vontade do velho regime. Nenhum governo pode manter-se no poder por longo prazo, se não contar com o apoio da opinião pública, isto é, se os governados não estiverem convencidos de que o governo é bom (Mises, 1987b, p. 42 e 43).

Para o economista austríaco, um governo com estas características só tem lugar em sociedades de mercado e em regimes democráticos. Regimes transparentes, não autoritários, parciais e fascistas. Quanto ao governo, a existência de limites se faz mais do que necessária. Toda ação governamental quando justa deve ser tomada pela maioria. No entanto, muita atenção deve ser dispensada a esta ação. Ela deve ser regulada por firmes limites, objetivando sua legitimidade e não abrindo possibilidades para a tirania. 
Mises também vê com desconfiança os regimes democráticos, especialmente os que se denominam puros. Contudo, tem a consciência de que tais regimes se configuraram como "melhores alternativas" para a vida em uma sociedade que preserva a liberdade e o direito de propriedade.

A noção de distinção e dignidade especiais, ligadas ao exercício de todas as funções governamentais, é o que constitui a base da pseudodemocrática teoria do Estado. Segundo esta doutrina, é uma vergonha para qualquer um deixar-se conduzir pelos outros. Seu ideal é uma constituição, pela qual todo o povo legisla e governa. Sem dúvida alguma, isto nunca foi, não é, nem será possível, nem mesmo sob as condições reinantes em um pequeno Estado (Mises, 1987b, p. 41 e 42).

Mises afirma que a democracia direta, "sonho de intelectuais românticos", jamais foi ou será alcançada. Nem mesmo nas cidades-Estados da Grécia Antiga, ou nos pequenos cantões das montanhas suíças este ideal fora alcançado. Sabe-se que no caso grego apenas uma parte da população, os cidadãos livres, participavam com legitimidade de fala e voto do governo. Aos estrangeiros e escravos pouco ou nada era garantido. No caso suíço, de acordo com o economista, toda experiência se resumiu na votação de algumas matérias, de caráter puramente formal e local. Portanto, temos mais é que nos contentar com a presença do governo e de governantes, e acreditar em instituições que sejam justas e democráticas capazes de punir aqueles que transgridem as regras do acordo.

Ser governado por outros, não é, em absoluto, vergonhoso. O governo e a sua administração, a aplicação de normas policiais e arranjos semelhantes também requerem especialistas: servidores civis profissionais e políticos profissionais. O princípio da divisão do trabalho não perde a validade abruptamente, mesmo no que se refere às funções do governo. Não se pode ser um engenheiro e policial ao mesmo tempo. De modo algum, o fato de eu não ser um policial diminui minha dignidade, meu bem-estar ou minha liberdade. $O$ fato de que algumas pessoas tenham a responsabilidade de dar proteção a alguém não é mais antidemocrático do que o fato de que algumas outras tenham de produzir sapatos. Não há a menor razão para objetar a existência de políticos profissionais e servidores públicos profissionais, se as instituições do Estado são democráticas. Mas a democracia é algo completamente diferente do que imaginam visionários românticos, que vivem a balbuciar sobre a democracia direta (Mises, 1987b, p. 42). 
Contra o risco de os "adversários da democracia” gerenciarem o Estado concentrando poder nas mãos de uma minoria, Mises afirma a necessidade de criar mecanismos capazes de se interpor entre os indivíduos e o Estado. Estes mecanismos dizem respeito à permanência, maturação e desenvolvimento de regras capazes de garantir a propriedade privada. A seu ver, essa propriedade gera para o indivíduo um universo pelo qual ele pode se antepor, se defender ou mesmo ficar livre do Estado. Associada a um poderoso sistema de justiça, a propriedade privada, oferece aos homens e as mulheres poderes para se imporem à autoridade autoritária. E mais, forja o surgimento de novas forças, que também se colocam lado a lado, ou em oposição ao poder político. Não é por acaso que muitos governos criaram fortes restrições à propriedade privada. Ao se fortalecerem, os indivíduos proprietários colocaram em dúvida as diretrizes governamentais. Impediram abusos de poder e, dentro das regras democráticas, fizeram com que o Estado revisse sua delegação.

Entretanto, a despeito de todas as perseguições, a instituição da propriedade privada sobreviveu. Nem a animosidade de todos os governos, nem a campanha hostil feita contra ela por escritores e moralistas e por igrejas e religiões, nem o ressentimento das massas (profundamente enraizado na inveja instintiva) lograram aboli-la. Toda a tentativa de substituí-la por algum outro método de organização da produção e distribuição, por si mesma, tem sempre se mostrado, de pronto, infactível, e chegado às raízes do absurdo. As pessoas têm sido obrigadas a reconhecer que a instituição da propriedade privada é indispensável e a ela se tem convertido, quer gostem quer não (Mises, 1987b, p. 70).

Mises rechaça qualquer interferência do Estado, salvo as que servem para garantir a paz, a segurança, a liberdade e a propriedade privada dos meios de produção. No que concerne a defesa da justiça social e à construção do bem comum, de acordo com o economista austríaco, a defesa destes ideais, quando ultrapassam a liberdade individual e invadem o direito de propriedade, não passam de poderosos álibis ou ações hipócritas de grupos corporativos ansiosos por fazerem valer os seus próprios interesses às custas do Estado e daqueles que o ajudam a sobreviver através do pagamento de impostos. Mises não acredita em ações altruístas. Para ele, estamos falando de ações e condutas interessadas de seres humanos que desejam vencer no mercado. A única possibilidade de justiça é a da garantia que o Estado pode oferecer para que a lei seja rigorosa e aplicada a todos sem qualquer distinção. 


\section{Lucio Alves de Barros \\ Caio César Sousa Marçal}

A ação estatal não deve se ocupar de serviços sociais. Os poderes estatais não fazem justiça quando obriga o indivíduo a contribuir para os seus objetivos. Se homens e mulheres têm o interesse de serem caridosos, que o façam no mercado, usufruindo da liberdade e da transparência. Como se sabe, dificilmente os que pagam os impostos e os serviços sociais sabem a da real necessidade e dos custos de tais serviços. Nessa linha de raciocínio, taxar um pouco mais, através de impostos progressivos os mais abastados é injustiça. Deixar estes homens livres para investir no mercado é o melhor caminho para uma economia genuinamente liberal.

\section{A Deificação do mercado}

No início do século XVIII o liberalismo legitimou a propriedade privada. O homem se adaptou à "divindade" e o Iluminismo elevou a razão como o único guia do ser humano. A ação humana passou a ser central e a propriedade uma conquista via "competência". As teorias liberais consagraram o indivíduo como ação, germe e destinatário de todo conhecimento e poder político. A ação individual passou a ser o ponto de partida e chegada. Nada podia destruir o império da individualidade (vida, liberdade, conhecimento), pelo contrário, tudo podia ser criado. A teoria liberal exercerá grande influência em Mises que, em oposição ao holismo da tradição marxista, desenvolverá um pensamento econômico baseado na instituição do mercado e da ação humana. Para Mises, é o indivíduo, notadamente o consumidor, que compõe e tem a possibilidade de dar sentido e significado à realidade social. O individualismo de Mises, decorrente de sua formação intelectual, o levará naturalmente a eleger o indivíduo como "ser epistêmico", ou seja, ser capaz de apreender o real e criar a realidade.

Em sua obra Liberalismo (publicada em 1927), Mises demonstra o que defende ser uma doutrina genuinamente liberal. Criterioso, expõe com clareza os fundamentos do liberalismo. Sua análise não se resume ao mercado, trata do conceito de liberdade, propriedade privada e comunal, tolerância, paz, Estado, governo, igualdade, democracia, riqueza, partidos políticos dentre outros. Descreve como deveria ser construído um governo livre e democrático alicerçado em princípios liberais. Examina os problemas que podem gerar o intervencionismo, o nacionalismo, as políticas internacionais, o direito de autodeterminação, o imperialismo, o colonialismo e o comércio internacional.

Partindo do indivíduo como realidade objetiva, Mises reivindicará para a ciência econômica um estatuto metodológico próprio. A busca de 
uma ciência que entenda a ação humana é que está em jogo. O argumento principal é que a ação humana é radicalmente intencional: A tese central do liberalismo de Mises implica na constituição de duas proposições que se tornam interdependentes: a primeira afirma que é sempre possível reduzir os fenômenos sociais a resultados de decisões e ações individuais; a segunda diz que tais decisões e ações humanas estão sob os imperativos do mercado e da propriedade privada.

Comecemos pela primeira observação. Em poucas palavras, podese afirmar que o homem à luz do liberalismo de Mises depende do cálculo racional e do interesse próprio para conseguir almejar um fim determinado. A economia positiva nos oferece para esta concepção a expressão "Homem Econômico Racional" que é entendido da seguinte maneira: Em primeiro lugar, o homem naturalmente busca ou defende o seu alto interesse. O seu comportamento se direciona para maximizar os seus ganhos, para isso não interessa os meios que utilize. Entretanto, a lógica da maximização possui conteúdo ético: maximizar é um comportamento considerado correto para o indivíduo e para a sociedade. Maximizar é inerente a um padrão cultural que comporta a moral e o "dever ser".

Em segundo lugar, o homem racionalmente escolhe os melhores meios para se chegar ao fim desejado. A racionalidade é instrumental, dado que o homem buscará os meios materiais para a satisfação de suas preferências mais altas ao menor custo possível, mesmo correndo riscos e incertezas. $\mathrm{Na}$ verdade, tais teses não são novas. Adam Smith, o pai da economia política. A filosofia social de Adam Smith tem por base a fundamentação ontológica na qual o egoísmo e o naturalismo da troca são atributos naturais e constitutivos da espécie humana. Ao contrário dos animais, seres humanos possuem o poder de intercambiar o produto do seu trabalho, ou seja, o de trocar o bem produzido ou os seus serviços por outros produtos que necessita. Daí a importância que Adam Smith observa na divisão do trabalho em relação ao mercado. A defesa de Adam Smith (1981) do homem racional é plena. Para ele, a faculdade da razão e da linguagem do ser humano possibilitou o desenvolvimento do hábito peculiar de intercambiar os resultados do trabalho. A troca aparece como o elemento chave para garantir a liberdade e a sobrevivência. Além disso, o impulso para o ganho através da troca precede a divisão do trabalho e o mercado ou mesmo os determinam.

Em Adam Smith, este homem é propenso à troca e ao ganho. O economista nada vê de negativo nesta aspiração (o mesmo entende Mises), 


\section{Lucio Alves de Barros \\ Caio César Sousa Marçal}

pois defende que o livre curso do auto interesse privado resulta o bem público e a prosperidade através da intermediação do mercado. Para o autor, nada deve privar ou interferir na liberdade dos indivíduos, pois corre-se o risco de amputar a "mão invisível" que "representa aqui a noção de uma ordem espontânea que transforma através do mecanismo de mercado, e a partir de alguns pressupostos iniciais restritos, 'vícios privados' (egoísmo, ganância) em 'benefício público' (sistema econômico coerente e próspero)”, conforme assinala Fonseca (1987).

Assim, homem à luz desta abordagem é um feixe de desejos. Revela-se como um animal complexo e vitalizador de ação, faz parte da natureza como qualquer outro ser e está sujeito a leis empíricas passíveis de descoberta. Se para as ciências humanas, o seu comportamento deve ser explicado como resultado de uma série de tentativas para obter o que deseja. A questão não é tal como os filósofos racionalistas e empiristas almejavam. Os seus desejos não são metafísicos, religiosos ou éticos, são racionais voltados para a satisfação de desejos individuais, se são egoístas ou altruístas dependerá da situação social empírica em que está inserido. Cabe ressaltar que a escolha dos meios deve assegurar os seus fins, dado o impacto da ação do homem em relação as aspirações dos outros. E, como vimos acima, a maximização dos interesses e desejos de cada um, racionalmente calculado e a longo prazo, contribui para a maximização de todos. O cálculo racional tem como resultado a maximização da utilidade coletiva.

Em seu livro O Mercado, Mises (1987c) promove a ideia de como o mercado assume um lugar especial de integração das ações humanas. Não é preciso um Estado forte, tampouco um déspota ou modelos políticos de propriedade pública. Como atores racionais, os seres humanos são capazes da manutenção da harmonia social. É neste aspecto que Mises aposta no mercado como a principal instituição de informações. Ele aparece como um processo de transmissão de informações representado por preços, salários, lucros altos e baixos, os quais atuam como mecanismos capazes de distribuir as informações necessárias entre os agentes econômicos que, de outra forma, seriam incapazes de saber, já que a massa colossal de fatos economicamente significantes está fadada a escapar-lhes.

O mercado não é um local, uma coisa, uma entidade coletiva. O mercado é um processo, impulsionado pela interação das ações dos vários indivíduos que cooperam sob o regime da divisão do trabalho. As forças que determinam 
a - sempre variável - situação do mercado são os julgamentos de valor dos indivíduos e suas ações baseadas nesses julgamentos de valor. A situação do mercado num determinado momento é a estrutura de preços; isto é, o conjunto de relações de troca estabelecido pela interação daqueles que estão desejosos de vender com aqueles que estão desejosos de comprar. Não há nada, em relação ao mercado, que não seja humano, que seja místico. O processo de mercado resulta exclusivamente das ações humanas. Todo fenômeno de mercado pode ser rastreado até as escolhas específicas feitas pelos membros da sociedade de mercado (Mises, 2017, p. 17).

O problema encontrado na livre ação das interações reside apenas quando há a intervenção de mecanismos (subsídios, tabelamentos, impostos dentre outros) que impedem o mercado de fluir livremente. Nesse caso, o ataque ao Estado e a qualquer forma de intervencionismo se faz necessário porque estas ações produzem mecanismos que influenciam a livre e a pura rede de informações do sistema de trocas (preços, salários, lucros, etc.) criadas naturalmente pelo mercado. Assim sendo, o mercado ocupa um lugar de divindade soberana, onipotente e cuja a finalidade última da humanidade converge para as ideias de sua visão radical de liberalismo.

"O Estado utiliza o seu poder exclusivamente com o propósito de evitar que as pessoas empreendam ações lesivas à preservação e ao funcionamento regular da economia de mercado... Assim, o Estado cria e preserva o ambiente onde a economia de mercado pode funcionar em segurança(Mises, 2017).

Contudo, a deificação do mercado, onde os seus conceitos sobre o liberalismo se tornam uma espécie de "evangelho" é notoriamente marcado em seu livro chamado de "Socialism: An Economic and Sociological Analysis", publicado em 1951. Parece que de tanto divinizar o mercado, em dado momento dessa obra, Mises, tão tomado de seu fervor religioso, está comprometido a fazer uma espécie de "guerra santa" e escolhe a religião cristã como seu alvo principal de críticas nessa obra. Em franco ataque a religião cristã e a Igreja, Mises vocifera contra esses com o fervor de um apologeta que deseja extirpar uma heresia maligna. No livro Socialismo, o cristianismo é retratado como uma expressão religiosa baseada no ódio e que intentava destruir o "admirável novo mundo" proposto pelo ideário liberal. Segundo Mises, 
A Igreja ressentiu-se fortemente da modernidade e do espírito moderno. Que surpresa, então, que ela tenha se aliado àqueles cujo ressentimento levou-os a desejar a dissolução deste admirável novo mundo, e que tenha explorado seu arsenal bem estocado como meio para denunciar o esforço terreno pelo trabalho e pela riqueza. A religião que chama a si mesma religião do amor tornou-se uma religião do ódio, em um mundo que parecia estar preparado para a felicidade. Quaisquer pretendentes a destruidores da ordem social moderna poderiam fiar-se no cristianismo como um líder (Mises, 1951, p. 423).

Conforme Mises, o liberalismo não é apenas superior moralmente ao cristianismo, mas também a sua influência teria convertido o mundo em algo muito melhor, algo que a religião cristã jamais seria capaz. Em suas palavras, o liberalismo teria restabelecido a humanidade ao mundo e à vida, devolvendo a humanidade ao mundo e à vida. Assim, Mises decreta que o liberalismo, entendido como o auge da modernidade, é a nata do pensar iluminismo racional que desfechou o "sopro da morte" na Igreja cristã.

O liberalismo é a flor daquele iluminismo racional que desferiu o sopro da morte no regime da antiga Igreja e do qual brotou a crítica histórica moderna. Foi o liberalismo que solapou o poder das classes que por séculos estiveram intimamente ligadas à Igreja. Ele transformou o mundo mais que o cristianismo sempre o fez (Mises, 1951, p. 423).

Contudo, é em Jesus, figura central para toda a cristandade, que Mises desfere a crítica mais ríspida.

No Reino de Deus os pobres serão ricos, mas os ricos estarão envoltos em sofrimento. Revisores tardios tentaram abrandar as palavras de Cristo contra os ricos, das quais a versão mais completa e vigorosa é encontrada no Evangelho de Lucas, mas resta um bocado suficiente para apoiar aqueles que encorajam o mundo a sentir ódio, a se vingar a assassinar e a queimar os ricos (Mises, 1951, p. 419).

Um dos pontos que tem chamado a atenção na sociologia da religião é sobre os possíveis intercâmbios entre o "sagrado" e o "profano". Segundo Durkheim (1996), a religião possui uma energia vital e unificadora. A religião cumpriria um papel conciliador entre a busca da sociedade no seu bem-estar grupal com as crescentes demandas e interesses dos indivíduos por auto realização num mundo cada vez mais moderno. Weber (2005) pondera sobre 
o lugar da reforma protestante para a constituição do capitalismo moderno, relacionando seus preceitos com o aparecimento de uma nova forma que forja as relações sociais que, em última análise, patrocina e caracteriza a produção de excedentes, bem como engendra a acumulação de capital.

Ao tratar da preponderância da religião e da sua produção de bens simbólicos, Bourdieu (2009) afirma que a religião como uma linguagem potente e que gera condições favoráveis de aceitabilidade no corpo social. Tal linguagem significante enseja penetrar nos poros da sociedade. Ademais, a religião delineia e arquiteta seu discurso como uma condição para homogeneizar-se com a finalidade de perpetuar sua própria existência.

Nesse sentido, é mister apontar que os signos e discursos do discurso religioso busca apresentar-se a partir de uma lógica totalizante e que define a razão da existência dos indivíduos e do mundo. Em outras palavras, enquanto uma ideologia, a religião impõe valores que determinam não apenas o lugar de seus fiéis seguidores na determinação de seus valores, mas também o lugar das diversas expressões de crenças que não comungam de seus ideais. Contudo, a força da eficácia simbólica do discurso religioso, conforme o próprio Bourdieu registra, é que esse está assentado sob o signo do sagrado. Assim, esse veste-se do manto da inquestionabilidade, ou seja, o locus de sua legitimidade está fundado num ser divino cujo os mortais não devem se arrogar desobedecer a seus preceitos.

Assim, se em Weber uma determinada a religião empregnou com parte de seus valores para forjar o que nomina como o espírito do capitalismo, em Mises o liberalismo radical é uma espécie de um "novo evangelho" que traz as boas novas do "Deus mercado". Se a religião em Durkheim é tem uma energia vital e unificadora que concilia o bem-estar grupal com interesses dos indivíduos por autorealização, em Mises o mercado é essa entidade divina em que toda realização humana passa por centraliza-lo como único ordenador da existência dos indivíduos. Se em Bourdieu a religião oferece signos incontestáveis que explicam a existência humana e que confere para esses o significado último de suas vidas, posto que a força da eficácia simbólica do discurso religioso torna seus regramentos incontestáveis aos olhos de seus fiéis, em Mises a deificação do mercado parece ter o interesse de dar aos seus apóstolos um lugar de oráculos dos novos tempos do capitalismo. Portanto, qualquer interpelação ou interrogação em torno dos valores do mercado, esse ente sacralizado por von Mises, não passa de um sacrilégio. Em suma, a retórica de Mises que deifica o mercado, parece interessado em cooptar 
a força própria do discurso religioso e tem por intuito converter o mundo para suas teses ultraliberais.

\section{Conclusão}

Em tempos de demandas sociais concretas como a saúde, a educação e segurança, não deixa de causar mal-estar a argumentação de Mises ao defender que cumpre ao Estado apenas ser o depósito de leis aplicáveis a todos que transgridem as regras. Interferir nos mecanismos de mercado é tocar na possibilidade dos lucros e dos preços não fluírem naturalmente. Eles são fonte de informação, motivação e ação humana.

A interferência no mercado corre o risco de paralisar os mecanismos garantidores do progresso e da liberdade, tornando-se uma blasfêmia. Como se vê, o autor também sacraliza a instituição da propriedade privada. Não seria exagero afirmar que o mesmo faz com a liberdade e com o mercado, considerando-os um bem, um meio e um fim em si mesmo. Como vimos, para Mises a liberdade é a ausência de qualquer coerção ou constrangimento. Existe coerção quando é colocado a serviço de terceiros ou à vontade de outros a liberdade individual.

Em sociedades voltadas para o mercado, um dos principais processos que os indivíduos se vêem obrigados é o da competição. Não importa se este comportamento pode ter por resultado a miséria ou a desigualdades de renda. Este é um preço inevitável a ser pago por aqueles que perdem no jogo do mercado. Não existe outra saída para a liberdade. Por isso, o mercado é deificado por Mises, nele tudo começa e termina. E apenas o mercado deve determinar as normas da vida e da sociedade.

\section{Referências}

BERLIN, Isaiah. Dois conceitos de liberdade. In Quatro ensaios sobre a Liberdade. Brasília: Ed. UNB (Universidade de Brasília), 1981

BOURDIEU, Pierre. A Economia das Trocas Simbólicas. 6. ed. São Paulo: Perspectiva, 2009. DÜRKHEIM, Émile. As formas elementares da vida religiosa. São Paulo: Martins Fontes, 1996. FONSECA, Eduardo Giannetti da. Comportamento individual: alternativas ao homem econômico. Estudos Econômicos, v. 20, n. esp., p. 5-37, 1990. GIANETTI da Fonseca. Comportamento Individual: alternativas ao Homem Econômico. In Revista Estudos Econômicos. Instituto de Pesquisas Econômicas - USP, São Paulo, volume 20, número especial. 1990. 
MACCLLUM, G. C.. Negative and Positive Freedom. In: MILLER, David (ed.). Liberty. Oxford University Press, Oxford, 1991.

MERQUIOR, José Guilherme. Algumas reflexões sobre os liberalismos contemporâneos. Rio de Janeiro: Conferências, Instituto Liberal, dezembro de 1991. 27 p.

MERQUIOR, José Guilherme. Guerra ao Homo Economicus. In: O argumento liberal. Rio de Janeiro: Ed. Nova Fronteira, 1983.

MERQUIOR, José Guilherme. O Liberalismo: antigo e moderno. Trad. Henrique de Araújo Mesquita. Rio de Janeiro: Ed. Nova fronteira, 1991. 260 p.

MERQUIOR, José Guilherme. Renascença dos liberalismos: a paisagem teórica. São Paulo: Revista Lua Nova. Cultura e Política. Vol. 04, n. ${ }^{\circ}$ I , julho / setembro de 1987, n. ${ }^{\circ} 13$.

MILLER, David (ed.). Liberty. Oxford University Press, Oxford, 1991.

MISES, Ludwig von. A ação humana. LVM Editora, 2017.

MISES, Ludwig von. A mentalidade anticapitalista. Rio de Janeiro: Ed. José Olympio / Instituto Liberal, 1987a.

MISES, Ludwig von. Liberalismo: segundo a tradição clássica. Trad. Haydn Coutinho Pimenta. Rio de Janeiro: Ed. José Olympio / Instituto Liberal, 1987b.

MISES, Ludwig von. O mercado. Trad. Donald Stewart Jr.. Rio de Janeiro: Ed. José Olympio / Instituto Liberal, 1987c.

MISES, Ludwig von. Socialism: An Economic and Sociological Analysis. Macmillan Company, 1951.

MISES, Ludwig von. Uma crítica ao intervencionismo. Trad. Arlette Franco. Rio de Janeiro: Ed. Nórdica / Instituto Liberal, 1977.

RAWLS, John. Uma Teoria da Justiça. Trad. Almiro Pisetta \& Lenita M. R. Esteves. São Paulo: Ed. Martins Fontes, 2000. O original data de 1971.

SMITH, Adam. Uma investigação sobre a natureza e as causas da Riqueza das Nações. São Paulo: Ed. Hemus, 1981.

STEWART Jr., Donald. O que é o Liberalismo. $4^{a}$ ed.. Rio de Janeiro: Edição, Instituto Liberal, 1990.

WEBER, Max. A ética protestante e o espírito do capitalismo. Trad. Irene e Tamás Szmerecsányi. São Paulo: Pioneira Thompson Learning, 2005.

Submetido em: 12-7-2019

Aceito em: 7-5-2020 